\title{
A PRELIMINARY QUANTITATIVE ANALYSIS OF RURALITY IN ROMANIA AND THE IMPACT OF COMMON AGRICULTURAL POLICY SUBSIDIES
}

\author{
Nicola GALLUZZO
}

\author{
Address: \\ Association of Geographical and Economic Studies of Rural Areas (ASGEAR), Via Salaria per L'Aquila 76 scala A, \\ 02100 Rieti, Italy \\ Author's e-mail: asgear@libero.it
}

\begin{abstract}
In the literature, many studies have sought to assess through a quantitative approach the principle relationships between quantitative variables correlated to rurality. The impediment to such studies arises from the impossibility of quantitatively assessing cause-effect relationships between variables. The core purpose of this research was to assess by a quantitative approach the main cause-effect relationships in counties of Romania over the years 2007 to 2016 , in order to identify variables affecting the rurality index. The study used Partial Least Squares Structural Equation Modelling following the bootstrap methodology. The research outcomes highlighted the notable and positive role of financial subsidies allocated by the second pillar of the Common Agricultural Policy and specifically, the payments in favour of disadvantaged rural areas in relation to the rurality index across all regions of Romania. Some decoupled payments allocated within the framework of the first pillar of the CAP were found to have had no effect on crop farming. Drawing conclusions from this research, the financial support disbursed by the rural development programme is a fundamental stimulus to the reduction of socioeconomic marginalisation in Romanian farms and farming areas.
\end{abstract}

Keywords: rural development, Partial Least Square Structural Equation Modelling, rural areas, emigration, agritourism JEL: Q10, Q18

\section{INTRODUCTION}

The concept of rurality and its implications has been investigated in depth in the context of different European countries (Galluzzo, 2018a; 2018b; 2017; Kendall, 1975; Cloke, 1977). The core purpose of these studies was to identify "rurality" and its specific definition (Kendall, 1975; Cloke, 1977; Cloke and Edwards, 1986; PrietoLara and Ocaña-Riola, 2010; Ocaña-Riola and Sánchez-Cantalejo, 2005). In general, the assessment of an index of rurality has focused on investigating the impact of financial subsidies allocated by the European Union through the application of multiple regression modelling and Principal Component Analysis (PCA), which are both aimed at identifying the main correlations among variables. The drawback of this approach is the apparent difficulty of quantifying the cause-effect relationships that exist between variables (Galluzzo, 2018a; Finco et al., 2005). These latter authors used multiple regression models and PCA in studies conducted in several regions of central Italy, where many farming enterprises are located in disadvantaged rural areas. The primary objective of the analysis was to assess what role and to what effect the rural development initiatives financed by the European Union and, specifically, the second pillar of the Common Agricultural Policy have had over time (Finco et al., 2005; 2006). Through the use of multiple regression models and Principal Component Analysis, it has been possible to assess whether there are some statistically significant correlations and relationships between variables in respect to rural development. The main impediment in such studies, however, is their inadequacy in estimating the cause-effect relationships that exist in rural development in terms of whether the investigated variables exercise an enhancing or weakening effect in relation to rural areas. The primary purpose of the use of these methods has been to define a quantitative index tightly correlated to rural development, investigated through studies of countries that have recently joined the European Union (Galluzzo, 2016; 2018a; 2018b; Duvernoy et al., 2018). However, a notable issue in the estimation of such a rurality index is the conceptual identification of rurality itself. In many cases it has been investigated predominately according to a meaning and a quantitative criterion of rurality as proposed by certain institutions, e.g. the European Union, the OECD, and other entities (Galluzzo, 2018a; 2018b). For these public institutions, population and surface density represent pivotal variables fundamental for discriminating and distinguishing rural areas from urban ones.

Various authors (Galluzzo in 2018a, Cloke in 2006, Woods in 2010, and Prieto-Lara and Ocaña-Riola in 2010) have used selected socio-economic variables in a quantitative approach in order to define rurality in certain European countries. The limitation of seeking to conceptualise a univocal definition of rurality, however, is related to the fact that rurality itself is actually a multidimensional concept (Cloke, 2006; Woods, 2010). Nevertheless, a quantitative index that is able to assess rurality and the cause-effect relationships that have an influence on it is considered pivotal in estimating the impact of financial measures and socio-political strategies 
(Galluzzo, 2018a; 2018c).

Many scholars have investigated rurality in depth according to a quantitative approach, defining a specific index directly correlated to it (Kendall, 1975; Cloke, 1977; Cloke and Edwards, 1986; Prieto-Lara and Ocaña-Riola, 2010; Ocaña-Riola and SánchezCantalejo, 2005). According to these authors, the index of rurality has been established using available data for certain relevant quantitative socio-economic variables in some countries, e.g. Spain, the United Kingdom, and Italy. As several authors have argued, however, one of the major weaknesses of studies aimed at estimating the index of rurality is tightly related to their own target of investigation (Kendall, 1975; Cloke, 1977; Cloke and Edwards, 1986; Prieto-Lara and Ocaña-Riola, 2010; Ocaña-Riola and Sánchez-Cantalejo, 2005). These studies have formulated models capable of assessing direct or indirect correlations among variables, but they neither assessed nor explained the cause-effect relationships between the investigated variables.

A review of the literature available, relating to some Italian regions and Romanian counties, has highlighted the fact that rurality has been significantly influenced by direct and indirect payments disbursed by the European Union (Galluzzo, 2016; 2017); hence, research findings have strengthened the perception of the role and function of financial subsidies and aid allocated by the European Union through the Community Agricultural Policy for the purpose of ensuring the social protection of disadvantaged areas within rural territories (Galluzzo, 2016; 2017). The above-mentioned studies have also underlined the role of crop specialisation and diversification in farm production as variables fundamental to ensuring an adequate socioeconomic development in rural territories.

On the other hand, the literature review reveals a rather limited application of non-parametric models based on cause-effect analysis (Galluzzo 2018b; Bassi et al., 2016) using Partial-Least-Square Multiple Regression Models (PLS-SEM) in the scope of agricultural economics and rural development. The cause-effect approach using a non-parametric methodology adapts itself well to the objectives of investigating and estimating the rurality index due to the infinite number of variables involved and the lack of an underlying statistical distribution in the data. Furthermore, the small sample size which is the target of this investigation, namely the different Romanian counties, is not adequate to use a parametric approach where the methodology and the theoretical framework of investigation is not well defined (Hair et al., 2016; Wong, 2013). The use of PLS-SEM however, does not have consolidated methodology that can be tested with all its assumptions in other contexts of study.

According to the findings of the bibliographic research, the use of cause-effect PLS-SEM models has not been very common in the research carried out to date in European countries in the field of rural development and in studies of the relationships between socio-economic variables that have the primary aim of evaluating the rural index and the role of the Common Agricultural Policy in reducing marginalisation in rural territories. This is particularly the case in respect to the new member states of the European Union which joined after the second enlargement in 2007 (Galluzzo, 2018a; 2018b; 2016). The core purpose of this paper, therefore, was to assess by a quantitative approach the main cause-effect relationships of financial subsidies allocated by the Common Agricultural Policy and other socioeconomic variables correlated to the rurality in Romanian counties from 2007 to 2016 (Tab. 1). The main objective of the research was to identify an index of rurality that is able to explain the path of rural development in Romania, focusing the research objective on evaluating the part played by European funds allocated by the Community Agricultural Policy (CAP), both in the first and also the second pillar, on the overall rural development in order to test the effects of the CAP.

The analysis of an index of rurality and the effects that the Common Agricultural Policy has had in the socioeconomic growth of rural areas through financial subsidies and aid allocated by the second pillar, comparing Romania to other European countries, has not been sufficiently investigated in depth, hence this research represents an innovation within the framework of agricultural and rural economics aimed at defining, through a quantitative methodology, an indicator of rurality and rural development.

\section{DATA AND METHODS}

The source of the data used for this study were the findings of the Farm Accountancy Data Network (FADN), as well as the statistical dataset published in the TEMPO time series by the Romanian Institute of Statistics (INSSE).

The structural equation models (SEM) used in this research examined the linear relationships between dependent and independent variables, measured through a direct process of investigation or otherwise, when it was not possible to observe them directly, assessed through an indirect approach (Faraci and Musso, 2013; Di Franco, 2015; Lovison and Olivieri, 2002; Steiger, 1990). The analysis of a parametric model proposed by the SEM was not adequate to our objectives. Hence, considering the small size of the units of observations, the non-parametric Partial Least Square-Structural Equation Modelling (PLSSEM) was preferred.

The key element of measurement of the models is based on structural equations, including the Partial Least Square Structural Equation Model, that have the purpose of defining the latent variables that are not directly observable, such as the rurality index.

The methodology was based on the elaboration and measurement of a pattern of random relationships that are included in the model, followed by the estimation of variances and covariances between all the investigated variables, and a subsequent phase of evaluation of the estimated matrix, fundamental in assessing whether the data contained in it are compatible with the observed matrix (Faraci and Musso, 2013; Di Franco, 2015; Lovison and Olivieri, 2002; Steiger, 1990). All this will enable the confirmation or refutation of the basic hypotheses formulated regarding the cause-effect relationships. However, there is no well-defined and already tested methodology for measuring cause-effect relationships that can be applied in order to estimate the 
index of rurality and the impact of financial subsidies allocated by the CAP; hence, in the light of the small sample size used in this research, the PLS-SEM is considered fairly adequate for the objectives of our research (Hair et al., 2016; Hair et al., 2017).

In fact, as reported by these authors, particularly in regards to the space-time comparison, comparing the units of investigation both between the provinces and also over the years of study, the modest sample of farming enterprises useful for the research requires the use of PLSSEM approach.

The assessment of the cause-effect model in a pattern of investigation of rural development and the growth of socio-economic marginalisation requires a Structural Equation Model (SEM) which has to be modified in line with the specifications proposed in the Partial Least Square Structural Equation Modelling approach (PLSSEM) of fitting well to the features of the analysis and to the theoretical framework proposed by different authors (Tenenhaus et al., 2004; Hair et al., 2017; Hair et al., 2016; Galluzzo, 2018a; 2018b).

The Partial Least Square-Structural Equation Model is a non-parametric model without restrictive underlying assumptions that can be applied to the estimation of the main correlations and links between variables in a modest sized sample of study. Moreover, there is no a priori hypothesis to test (Awang et al., 2010; Wong, 2013).

In fact, the PLS-SEM is considered adequate to our target analysis because of the modest sample of farming enterprises in the dataset, and also because of the absence of a theory or theoretical framework of investigation that have previously been tested, unlike studies in other fields such as psychometrics and psychology. Furthermore, the PLS-SEM is a good fit for the purpose of the study because there are no issues linked to predictive accuracy, there are no constraints related to the definition of a well codified measurement scale such as, for example, the Linkert scale, and because there is no stringent requirement to define a priori specifications in the model.

The Partial Least Square fits well to estimating some relationships from a small sample of farming enterprises, even if an overall dimension of 100 to 200 units is a fundamental and basic starting point for assessment, since the lower the number of the sample, the more modest is the quality of the results (Hoyle, 1995; Wong, 2013; Galluzzo, 2018a; 2018b; Hair et al., 2017; Hair et al., 2016; Wong, 2013; Awang et al., 2015; Henseler et al., 2015). Generally speaking, Partial Least Square Structural Equation Modelling describes the causality amongst latent variables through an iterative methodology aimed at estimating the internal and external correlations and values for all investigated latent variables (Hair $\boldsymbol{e t}$ al., 2016; Henseler et al., 2015; Wong, 2013; Vinzi et al., 2010; Tenenhaus et al., 2004; Lowry and Gaskin, 2014). According to these authors, the partial estimation approach uses a different set of socio-economic and technical variables, stratified in several blocks of variables which alternate simple and multiple regressions.

In function of the direction of the arrows between the latent variables, both in the SEM and also in the PLS$\mathrm{SEM}$, it is possible to estimate a formative or reflective measurement model (Hair et al., 2016). In the formative model, each indicator is the dimension of the latent variable and it builds the latent variable. In contrast, in the reflective model, the indicators are representative of the latent variable. In Partial Least Square Structural Equation Model which is based on the same approach and theoretical framework described and used in Structural Equation Modelling, it is necessary to estimate two different sub-models, defined as the inner model, comprising the interactions between the dependent and independent variables, and the outer model, which is based on certain key relationships between latent variables and their factors or indicators (Hair et al., 2016; Henseler et al., 2015; Wong, 2013). Variables have been split into two main groups and stratified as exogenous variables which are not affected by other variables, represented with path arrows pointing outwards and which do not receive any other arrows inwards, and endogenous variables that are dependent and determined by functional relationships with other variables, represented with one or more arrows leading towards them (Hair et al., 2016; Hair et al., 2017; Wong, 2013; Vinzi et al., 2010; Awang et al., 2015; Henseler et al., 2015).

For the purposes of this study, the most suitable software is Smart-PLS version 3.2.7 (Ringle et al., 2015). The statistical data was gathered from two sources, namely the Farm Accountancy Data Network and some datasets published by the Romanian national statistical institute TEMPO time series, with the objective of obtaining a homogeneous dataset for the period 2007 to 2016, and was then normalised prior to assessment in the PLS-SEM. The estimation of the equation applied in the Partial Least Square Structural Equation Modelling can be written as in Eq. 1 (Haenlein and Kaplan, 2004):

$\eta=\gamma_{x_{1}} x_{1}+\gamma_{x_{2}} x_{2}+\gamma_{x_{3}} x_{3}+\zeta$

Where: $\eta$ is the latent variable; $\gamma_{x_{1}}, \gamma_{x_{2}}, \gamma_{x_{3}}$ the coefficients; $x_{1}, x_{2}, x_{3}$ the indicators which are the measurable variables in this research; $\zeta$ is the statistical error.

In the PLS-SEM, the estimation process of the weights $\left(w_{i}\right)$ is made in two different steps (Haenlein and Kaplan, 2004), assessing the latent variable $\eta$ as a weighted average of different indicators, hence $\eta$ equates to $w_{1} x_{1}+w_{2} x_{2}$ estimated in a similar way as in Principal Component Analysis in the case of reflective constructs, or by regression modelling in the case of formative constructs (Haenlein and Kaplan, 2004; Cassel et al., 1999). According to these authors, the next stage in the process of estimation is the internal approximation assessed as a weighted average of the neighbouring latent variables, written as in Eq.2. These procedures are repeated until convergence is achieved.

$\eta_{2}=W_{1} Y_{3}+W_{2} Y_{4}$

Where: $\eta_{2}$ is the latent variable assessed in the model; $W_{1}, W_{2}$ are the weights; $Y_{3}, Y_{4}$ are the indicators in terms of measurable variables 


\section{RESULTS AND DISCUSSION}

Findings in descriptive statistics have shown the permanent emigration to range between 15 to more than 3,500 people (Tab. 2). A significant variance has been observed in terms of GDP per capita which, expressed in Romanian LEI, ranged from a low of 2,770 to more than 178,000 (approximately $€ 594$ to $€ 38,000$, respectively) . A sharp rise has been observed in the number of farms specialising in agritourism, with an average value of 39 agritourism enterprises. This significant increase has been encouraged by financial subsidies amounting to $€ 841.71$ for each Romanian county, allocated through Pillar II of the Common Agricultural Policy, representing more than $1 / 15^{\text {th }}$ of the total financial subsidies disbursed under the first and second pillars of the Common Agricultural Policy. Across all Romanian regions, a significant percentage of the total amount of financial subsidies distributed under the second pillar of the Common Agricultural Policy were allocated to disadvantaged rural areas. Population growth was found to be negative, with average decreases of over 1,000 people.

Research outcomes in the regression model have revealed a strong correlation between emigration and the level of wealth expressed in terms of gross domestic product per capita and, in contrast, a week correlation between emigration and total financial subsidies allocated by the Common Agricultural Policy (Tab. 3). A weak correlation has been found between financial subsidies allocated to social protection and emigration. Among the variables, an indirect correlation has been assessed between gross domestic product in the primary sector and population growth, agritourism, and total subsidies for livestock farming allocated by the first pillar. A modest correlation has been found between the variable total decoupled payments and the variable total financial subsidies allocated by the CAP. To conclude, the highest level of correlation has been noted between the RDP variable, namely the direct payments allocated by the second pillar, and the variable LFA, representing payments made to less favoured areas.

Findings in the Partial Least Square Structural Equation Modelling have underlined a positive and high cause-effect relationship between the endogenous variable Economic aspects in Romanian counties (Economic) and the exogenous variable rurality index, with a $p$ value of less than 0.01 (Fig. 1). An indirect cause-effect relationship has been found to exist between the endogenous variable Financial subsidies allocated by the European Union to farmers (Agricultural funds) that comprises aid and indirect payments disbursed through the first and second pillars of the Common Agricultural Policy and the endogenous variable Economic aspects in Romanian counties (Economic), with a $\mathrm{p}$ value close to 5\%. The endogenous variables Population growth and other items (Population) and Expenditure on social welfare and protection (Welfare and protection) have underlined a positive correlation and a significant causeeffect relationship, with a p value lower than 0.01 .

In regards to the rurality index over the period of investigation, findings estimated using the bootstrap methodology have revealed a direct impact of the items agritourism, emigration, and LFA financial support, with a significance lower than $10 \%$.

Table 1: Main items and variables assessed in the PLS-SEM in 41 Romanian counties for the period 2007 to 2016

\begin{tabular}{lll}
\hline Item name & Unit & Description \\
\hline Agritourism & Farms (no.) & Farms specialised in on-farm activity hosting tourists \\
Emigration & People (no.) & People permanently emi grated \\
Agricultural branches GDP & LEI (Million) & Gross domestic product from the primary sector \\
GDP per capita & LEI & Gross domestic product per inhabitant \\
Social protection & Hectares (ha) & Subsidies allocated for social welfare protection \\
Agricultural area & People (no.) & Agricultural area used for agrarian crops \\
Unemployed people & LEU (Million) People without employment \\
Research expenses & LEU (Million) Public expenditure for research \\
Subsidies & People (no.) & Public subsidies for welfare \\
Population growth & Number (no.) & Population increase every year \\
Life expectancy & Years & Life expectancy \\
CAP & EUR & Total financial subsidies allocated by the first and second pillars of the CAP \\
Subsidies - crops & EUR & Decoupled Payments first pillar CAP to crop farming \\
Subsidies - livestock & EUR & Decoupled Payments first pillar CAP to animal farming \\
Decoupled payments & EUR & Total decoupled payments \\
RDP & EUR & Total payments allocated by the second pillar CAP to rural development \\
LFA & EUR & Payments to disadvantaged rural areas \\
\hline Variables & Typology & Description \\
\hline RURALITY & Exogenous & Index of rurality \\
Agricultural funds & Endogenous & Financial subsidies allocated by the European Union to farmers \\
Economic & Endogenous & Economic aspects in Romanian counties \\
Population & Endogenous & Population growth and other items \\
Welfare and protection & Endogenous & Expenditure on social welfare and protection \\
\hline
\end{tabular}


Table 2: Descriptive statistics investigated in in 41 Romanian counties for the period 2007-2016.

\begin{tabular}{lllll}
\hline Variable & Min. & Max. & Mean & Std. Deviation \\
\hline Emigrated people & 15.00 & $3,634.00$ & 270.46 & 259.95 \\
Agricultural branches GDP & $222,708.00$ & $3,797,052.00$ & $1,630,226.44$ & $576,846.81$ \\
GDP per capita & $2,770.00$ & $178,659.00$ & $11,371.49$ & $10,507.56$ \\
Social protection expenses & $8,578,946.00$ & $193,352,638.00$ & $42,128,821.89$ & $26,446,843.75$ \\
Agricultural areas & $3,052.00$ & $699,470.00$ & $356,242.31$ & $111,799.15$ \\
Unemployed people & $1,962.00$ & $33,643.00$ & $11,459.73$ & $5,376.39$ \\
Research expenses & 0.00 & $1,235,963.00$ & $43,346.89$ & $109,910.921$ \\
Total subsidies for welfare & 35.00 & 427.00 & 130.35 & 62.82 \\
Population growth & $-4,015.00$ & $2,728.00$ & $-1,103.00$ & $1,121.44$ \\
Agritourism & 0.00 & 352.00 & 38.69 & 56.42 \\
Life expectancy & 69.00 & 78.00 & 74.10 & 1.34 \\
Total subsidies excluding on investments & 0.00 & $82,357,729.00$ & $14,018,027.11$ & $13,923,502.60$ \\
Total subsidies for crops & 0.00 & $49,562,898.00$ & $6,429,675.83$ & $8,961,207.68$ \\
Total subsidies for livestock & 0.00 & $40,936,003.00$ & $1,644,254.61$ & $3,868,700.48$ \\
Total decoupled payments & 0.00 & $47,564,621.00$ & $5,053,892.33$ & $6,428,957.46$ \\
Total support for rural development & 0.00 & $39,560,920.00$ & $841,718.32$ & $3,133,300.82$ \\
Less Favoured Areas (LFA) payments & 0.00 & $39,560,920.00$ & $544,256.39$ & $2,703,718.46$ \\
\hline Sourc: Author's own elaboratin based & & & & \\
\hline
\end{tabular}

Source: Author's own elaboration based on data from:

FADN available at: http://ec.europa.eu/agriculture/rica/database/database_en.cfm

TEMPO time series available at: http://statistici.insse.ro

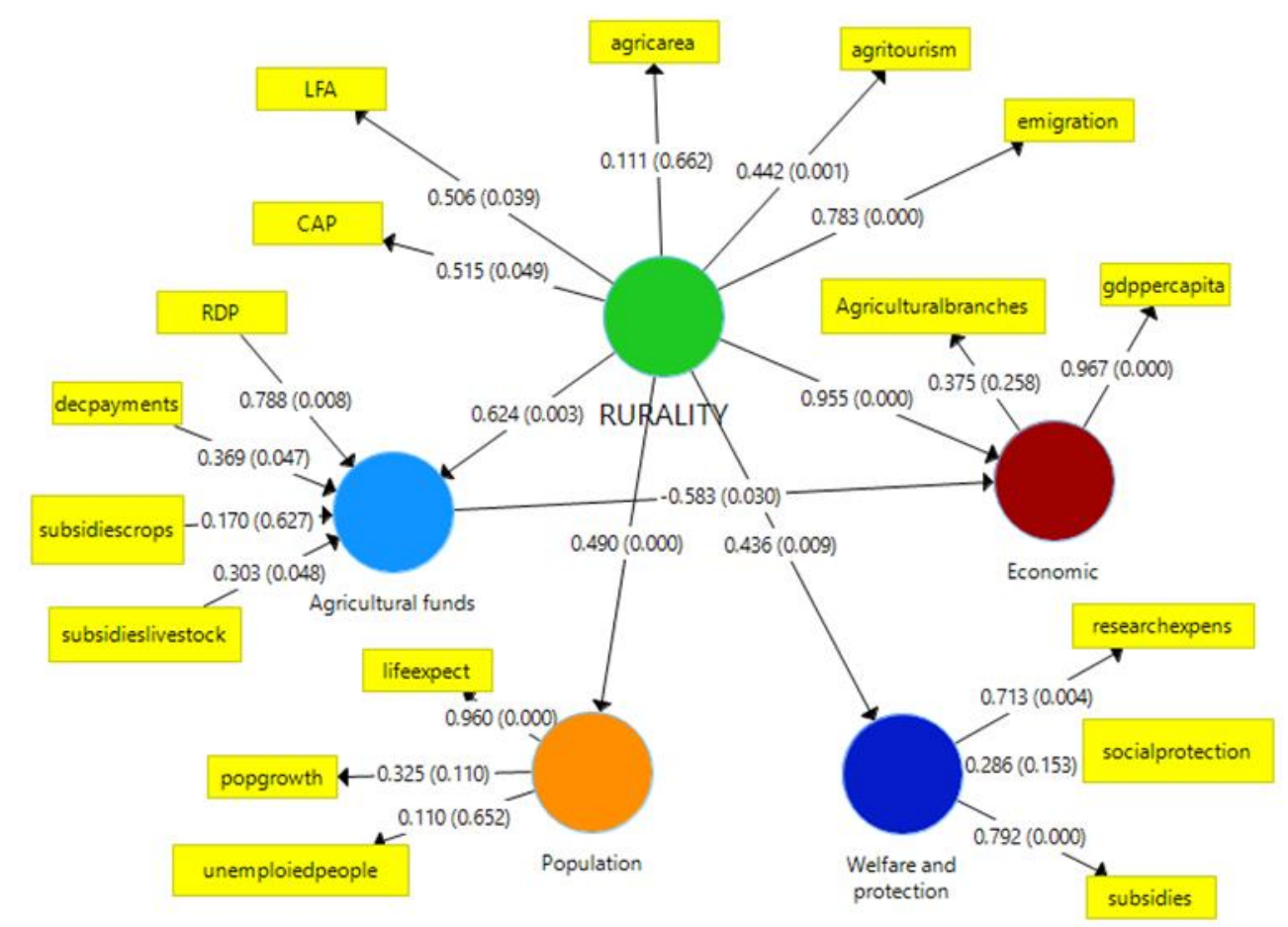

Figure 1: Main results in the index of rurality (RURALITY) estimated through the PLS-SEM assessed in all 41Romanian counties.

Source: Author's own elaboration based on data from:

FADN available at: $\mathrm{http}: / /$ ec.europa.eu/agriculture/rica/database/database_en.cfm

TEMPO time series available at: http://statistici.insse.ro 
Table 3: Main correlations between all investigated variables in Romanian counties.

\begin{tabular}{|c|c|c|c|c|c|c|c|c|c|c|c|c|c|c|c|c|c|}
\hline Variables & 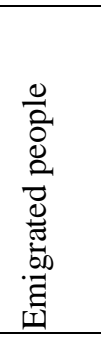 & 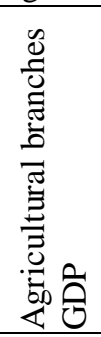 & 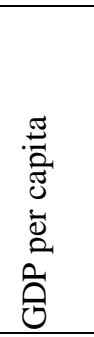 & 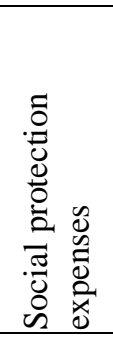 & 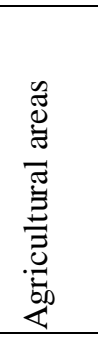 & 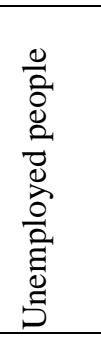 & 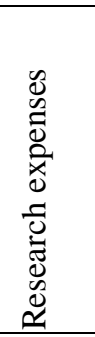 & 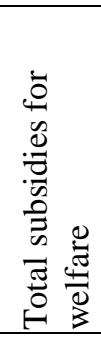 & 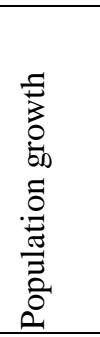 & 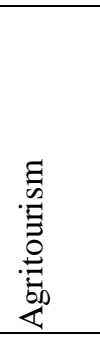 & 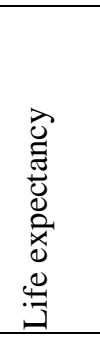 & 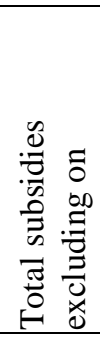 & 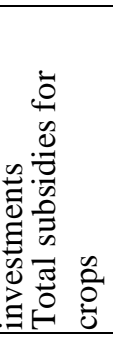 & 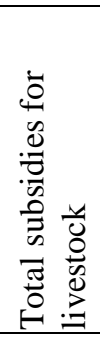 & 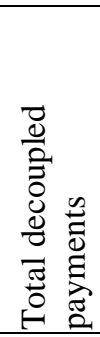 & 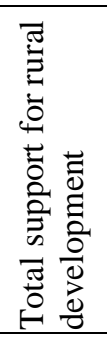 & 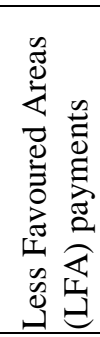 \\
\hline Emigrated people & 1.00 & 0.25 & 0.81 & 0.12 & 0.17 & 0.13 & 0.45 & 0.48 & 0.07 & 0.18 & 0.43 & 0.09 & -0.03 & 0.08 & 0.13 & 0.07 & 0.05 \\
\hline Agricultural branches GDP & 0.25 & 1.00 & 0.12 & 0.05 & 0.64 & 0.29 & -0.15 & 0.32 & -0.17 & -0.14 & 0.16 & -0.04 & 0.06 & -0.15 & 0.00 & -0.01 & -0.02 \\
\hline GDP per capita & 0.81 & 0.12 & 1.00 & 0.25 & 0.09 & 0.18 & 0.66 & 0.42 & -0.02 & 0.16 & 0.39 & -0.02 & -0.08 & 0.03 & 0.05 & 0.01 & 0.01 \\
\hline Social protection expenses & 0.12 & 0.05 & 0.25 & 1.00 & 0.07 & 0.65 & 0.05 & 0.10 & -0.06 & 0.15 & 0.03 & -0.07 & 0.02 & 0.00 & -0.17 & -0.06 & 0.00 \\
\hline Agricultural areas & 0.17 & 0.64 & 0.09 & 0.07 & 1.00 & 0.24 & -0.21 & 0.15 & -0.25 & -0.16 & -0.10 & 0.03 & 0.08 & -0.07 & 0.03 & -0.03 & -0.03 \\
\hline Unemployed people & 0.13 & 0.29 & 0.18 & 0.65 & 0.24 & 1.00 & -0.06 & 0.16 & -0.32 & 0.06 & 0.10 & -0.20 & -0.09 & -0.10 & -0.19 & -0.04 & 0.02 \\
\hline Research expenses & 0.45 & -0.15 & 0.66 & 0.05 & -0.21 & -0.06 & 1.00 & 0.18 & 0.17 & 0.06 & 0.27 & 0.02 & -0.05 & 0.04 & 0.10 & -0.01 & -0.03 \\
\hline Total subsidies for welfare & 0.48 & 0.32 & 0.42 & 0.10 & 0.15 & 0.16 & 0.18 & 1.00 & -0.07 & 0.12 & 0.54 & -0.05 & -0.21 & -0.09 & 0.29 & -0.01 & 0.00 \\
\hline Population growth & 0.07 & -0.17 & -0.02 & -0.06 & -0.25 & -0.32 & 0.17 & -0.07 & 1.00 & 0.25 & 0.07 & 0.07 & 0.00 & 0.20 & -0.04 & 0.08 & 0.07 \\
\hline Agritourism & 0.18 & -0.14 & 0.16 & 0.15 & -0.16 & 0.06 & 0.06 & 0.12 & 0.25 & 1.00 & 0.36 & 0.04 & -0.08 & 0.12 & 0.04 & 0.14 & 0.11 \\
\hline Life expectancy & 0.43 & 0.16 & 0.39 & 0.03 & -0.10 & 0.10 & 0.27 & 0.54 & 0.07 & 0.36 & 1.00 & 0.16 & 0.08 & -0.09 & 0.34 & 0.12 & 0.10 \\
\hline $\begin{array}{l}\text { Total subsidies excluding } \\
\text { investments }\end{array}$ & 0.09 & -0.04 & -0.02 & -0.07 & 0.03 & -0.20 & 0.02 & -0.05 & 0.07 & 0.04 & 0.16 & 1.00 & 0.77 & 0.37 & 0.60 & 0.37 & 0.31 \\
\hline Total subsidies for crops & -0.03 & 0.06 & -0.08 & 0.02 & 0.08 & -0.09 & -0.05 & -0.21 & 0.00 & -0.08 & 0.08 & 0.77 & 1.00 & 0.04 & 0.26 & 0.17 & 0.13 \\
\hline Total subsidies for livestock & 0.08 & -0.15 & 0.03 & 0.00 & -0.07 & -0.10 & 0.04 & -0.09 & 0.20 & 0.12 & -0.09 & 0.37 & 0.04 & 1.00 & 0.09 & -0.03 & -0.03 \\
\hline Total decoupled payments & 0.13 & 0.00 & 0.05 & -0.17 & 0.03 & -0.19 & 0.10 & 0.29 & -0.04 & 0.04 & 0.34 & 0.60 & 0.26 & 0.09 & 1.00 & 0.06 & 0.01 \\
\hline Total support for rural development & 0.07 & -0.01 & 0.01 & -0.06 & -0.03 & -0.04 & -0.01 & -0.01 & 0.08 & 0.14 & 0.12 & $\mathbf{0 . 3 7}$ & 0.17 & -0.03 & 0.06 & 1.00 & 0.93 \\
\hline $\begin{array}{l}\text { Less Favoured Areas (LFA) } \\
\text { payments }\end{array}$ & 0.05 & -0.02 & 0.01 & 0.00 & -0.03 & 0.02 & -0.03 & 0.00 & 0.07 & 0.11 & $\mathbf{0 . 1 0}$ & $\mathbf{0 . 3 1}$ & 0.13 & -0.03 & 0.01 & 0.93 & 1.00 \\
\hline
\end{tabular}

Note: In bold - values with a significance at $5 \%$.

Source: Author's own elaboration based on data from:

FADN available at: http://ec.europa.eu/agriculture/rica/database/database_en.cfm

TEMPO time series available at: http://statistici.insse.ro 
In contrast, the variables agricultural area and total financial subsidies allocated by the Common Agricultural Policy have not had any impact on the Rurality (Index of rurality) (Fig. 1). Focusing attention on the endogenous variable CAP, the items financial subsidies allocated by the second pillar and total decoupled payments in favour of livestock have revealed the existence of a direct correlation. The item subsidies for crops has had no effect on the item decoupled payments. The endogenous variable Population growth and other items (Population) shows the existence of direct cause-effect relationships with the item's life expectancy, population growth, and unemployment, with $\mathrm{p}$ values lower than 0.01 . The endogenous variable Expenditure on social welfare and protection (Welfare and protection) has been influenced by the items research expenses, social protection, and total subsidies allocated to Romania. Finally, the items GDP per capita and the GDP from the primary sector (Agricultural branches GDP) have had a direct impact on the endogenous variable Economic aspects in Romanian counties (Economic).

\section{CONCLUSION}

The estimation of the index of rurality in Romanian counties through the PLS-SEM using a bootstrap approach has revealed rurality to be an exogenous variable that is heavily influenced by the endogenous variable Economic aspects in Romanian counties (Economic) or, rather, by the economic items GDP per capita and GDP from the primary sector. A programme of subsidies in favour of lagging rural areas as well as financial aid allocated through the second pillar of the Common Agricultural Policy should be implemented with the primary objective of reducing the socio-economic marginalisation of these areas, even if the budget proposals recently announced by the EU Commission for the next seven-year period 20212027 do not seem very encouraging.

From the research findings, it is clear that the diversification of on-farm activities enabled by financing under Pillar II of the Common Agricultural Policy is fundamental to the rurality index, whilst emigration emerges as a core variable that influences it. Consequently, it can be seen that high levels of emigration have a stymying effect on the development of rural areas. Furthermore, the level of financial support allocated by the national Rural Development Programme over the next seven year period have to be increased. In particular, a pivotal role can be played by the LEADER programme, an EU initiative whose main purpose is to support cohesive local development through the revitalisation of rural areas and the creation of jobs in small rural villages at risk of socio-economic marginalisation. These villages are very sensitive to a bottom-up pattern of rural development and are extremely reliant on the financial support disbursed through the Common Agricultural Policy.

\section{REFERENCES}

AWANG, Z., AFTHANORHAN, W.M.A and ASRI, M.A.M. (2015). Parametric and non-parametric approach in structural equation modeling (SEM): the application of bootstrapping. Modern Applied Science, 9(9), pp. 58-67. DOI: http://dx.doi.org/10.5539/mas.v9n9p58.

BASSI, I., NASSIVERA, F. and PIANI, L. (2016). Market opportunities for social farms. Rivista di Economia Agraria, 71(2), pp. 97-110. DOI: http://dx.doi.org/10.13128/REA-20074

CASSEL, C., HACKL, P. and WESTLUND, A.H. (1999). Robustness of partial least-squares method for estimating latent variable quality structures. Journal of applied statistics, 26(4), pp. 435-446. DOI: http://dx.doi.org/10.1080/02664769922322.

CLOKE, P. (2006). Conceptualizing rurality. In: Cloke, P., Marsden, T. and Mooney, P. (Eds.), Handbook of rural studies, SAGE Publications, Thousand Oaks, pp. 18-28.

CLOKE, P. and EDWARDS, G. (1986). Rurality in England and Wales 1981: a replication of the 1971 index. Regional Studies, 20(4), pp. 289-306. DOI: http://dx.doi.org/10.1080/09595238600185271

CLOKE, P.J. (1977). An index of rurality for England and Wales. Regional Studies, 11(1), pp. 31-46. DOI: http://dx.doi.org/10.1080/09595237700185041

DI FRANCO, G. (2016). I modelli di equazioni strutturali: concetti, strumenti e applicazioni. Franconangeli, Milano.

DUVERNOY, I., ZAMBON, I., SATERIANO, A., and SALVATI, L. (2018). Pictures from the other side of the fringe: Urban growth and peri-urban agriculture in a postindustrial city (Toulouse, France). Journal of Rural Studies, 57, pp. 25-35. DOI: http://dx.doi.org/10.1016/j.jrurstud.2017.10.007

FARACI, P. and MUSSO, P. (2013). La valutazione dei modelli di equazioni strutturali. In: Barbaranelli C. e Ingoglia S. (eds) I modelli di equazioni strutturali. Temi e prospettive. LED Edizioni Universitarie di Lettere Economia Diritto, Milano, pp. 111-150.

FINCO, A., DI PRONIO, G. and POLLONARA, M. (2006). Politiche di sviluppo rurale per il paesaggio e la biodiversità: le regioni Marche e Abruzzo. In: Marangon F. (Eds.): Gli interventi paesaggistico-ambientali nelle politiche regionali di sviluppo rurale, Francoangeli, Milano.

FINCO, A., DI PRONIO, G. and POLLONARA, M., (2005). Multifunzionalità e sviluppo rurale delle zone montane. Rivista di Economia Agraria, 60(2), pp. 449468.

GALLUZZO, N. (2018a). An analysis of rurality index in Romanian countryside by a quantitative approach. Trakia Journal of Science, 16(2), pp. 134-139. DOI: http://dx.doi.org/10.15547/tjs.2018.02.010

GALLUZZO, N. (2018b). Impact of the Common Agricultural Policy payments towards Romanian farms. Bulgarian Journal of Agricultural Science, 24(2), pp. 199205.

GALLUZZO, N. (2018c). A non-parametric analysis of technical efficiency in Bulgarian farms using the FADN dataset. European countryside, 10(1), pp. 58-73. DOI: http://dx.doi.org/10.2478/euco-2018-0004

GALluZZO, N. (2017). The Common Agricultural Policy and employment opportunities in Romanian rural areas: the role of agritourism. Bulgarian Journal of Agricultural Science, 23(1), pp. 14-21. 
GALLUZZO, N. (2016). Role of financial subsidies allocated by the Common Agricultural Policy in reducing out emigration in Italian countryside. Romanian Journal of Regional Science, 10(2), pp. 50-63.

GALLUZZO, N. (2008). The impact of II pillar on the multifunctionality in Italian farms: analysis on the farm holidays. In: 109th Seminar European Association of Agricultural Economists, November 20-21, 2008, Viterbo, Italy.

HAIR, J.F., HULT, G.T.M., RINGLE, C. and SARSTEDT, M. (2016). A primer on partial least squares structural equation modeling (PLS-SEM). SAGE Publications, Thousand Oaks.

HAIR, J.F., SARSTEDT, M., RINGLE, C.M. and GUDERGAN, S.P. (2017). Advanced issues in partial least squares structural equation modeling. SAGE Publications, Thousand Oaks.

HAENLEIN, M. and KAPLAN, A.M. (2004). A beginner's guide to partial least squares analysis. Understanding statistics, 3(4), pp. 283-297. DOI: http://dx.doi.org/10.1207/s15328031us0304_4

HENSELER, J., HUBONA, G. and RAY, P.A. (2016). Using PLS path modeling in new technology research: updated guidelines. Industrial management \& data systems, $116(\mathbf{1}), \quad$ pp. 2-20. DOI: http://dx.doi.org/10.1108/IMDS-09-2015-0382

INGOGLIA, S. (2013). L'analisi fattoriale confermativa e le sue applicazioni ai problemi. In: Barbaranelli C. e Ingoglia S. (eds): I modelli di equazioni strutturali. Temi $e$ prospettive. LED Edizioni Universitarie di Lettere Economia Diritto, Milano, pp. 59-110.

KENDALL, M. (1975). Multivariate analysis. Charles Griffin \& Co. Ltd, London.

LOVISON, G. and OLIVERI, A.M. (2002). La valutazione della qualità dei servizi ospedalieri: applicazione dei modelli ad equazioni strutturali ad un caso reale. Statistica applicata, 14(3), pp. 315-330.
LOWRY, P.B. and GASKIN, J. (2014). Partial least squares (PLS) structural equation modeling (SEM) for building and testing behavioural causal theory: When to choose it and how to use it. IEEE transactions on professional communication, 57(2), pp. 123-146. DOI: 10.1109/TPC.2014.2312452

OCAÑA-RIOLA, R. and SÁNCHEZ-CANTALEJO, C. (2005). Rurality index for small areas in Spain. Social Indicators Research, 73(2), pp. 247-266. DOI: http://dx.doi.org/10.1007/s11205-004-0987-3

PRIETO-LARA, E. and OCAÑA-RIOLA, R. (2010). Updating rurality index for small areas in Spain. Social Indicators Research, 95(2), p. 267. DOI: https://doi.org/10.1007/s11205-009-9459-0

RINGLE, C.M., WENDE, S. and BECKER, J.M. (2015). SmartPLS 3. Bönningstedt: SmartPLS. DOI: http://www.smartpls.com

STEIGER, J.H. (1990). Structural model evaluation and modification: An interval estimation approach. Multivariate behavioural research, 25(2): pp. 173-180. DOI: https://doi.org/10.1207/s15327906mbr2502_4

TENENHAUS, M., VINZI, V.E., CHATELIN, Y.M. and LAURO, C. (2005). PLS path modeling. Computational statistics \& data analysis, 48(1), pp. 159-205. DOI: http://dx.doi.org/10.1016/j.csda.2004.03.005

VINZI, V.E., TRINCHERA, L. and AMATO, S. (2010). PLS path modeling: from foundations to recent developments and open issues for model assessment and improvement. In: Vinzi, V.E., Chin, W.W., Henseler, J. and Wang H. (Eds.), Handbook of partial least squares, Springer, Berlin Heidelberg, pp. 47-82. DOI: https://doi.org/10.1007/978-3-540-32827-8_3

WONG, K.K.K. (2013). Partial least squares structural equation modeling (PLS-SEM) techniques using SmartPLS. Marketing Bulletin, 24(1): pp. 1-32. 